\title{
Reliability Analysis Of Rotary Kiln A And Rotary Kiln B (Case Study: Pt. Meratus Jaya Iron \& Steel)
}

\author{
M. Rizki Ikhsan ${ }^{1}$, Agustina Hotma Uli Tumanggor ${ }^{2}$ \\ \{rizkiikhsan@unism.ac.id ${ }^{1}$, agustina@unism.ac.id ${ }^{2}$ \} \\ ${ }^{1}$ Department of Information Technology, Sari Mulia University, Banjarmasin, Indonesia \\ ${ }^{2}$ Department of Information Technology, Sari Mulia University, Banjarmasin, Indonesia \\ *rizkiikhsan@unism.ac.id
}

\begin{abstract}
By looking at the obstacles in PT. Meratus Jaya Iron \& Steel, which breaks down frequently on production machines, is a fundamental reason for researchers to increase the level of reliability of PT. Meratus Jaya Iron \& Steel. The study was conducted on a German-made Rotary Kiln machine whose role was quite high in the company. The method used is Reliability with the MTTR method. From the results of the calculation of reliability with the MTTR method on Rotary Kiln a namely Reliability at operating time of 296 hours obtained results of 0.5371 and MTTR 537.77732 and the calculation of Reliability with the method of MTTR on Rotary Kiln b namely Reliability at 296 hours operating time obtained results of 0,5371 and MTTR 537,7732. The higher the reliability value, the better the machine used in the operation process.
\end{abstract}

Keywords: Reliability, Weibull Distribution, Industrial Maintenance System

\section{Introduction}

In the industrial world, the product is the main result of a production process that forms a production process system. The production process system consists of inputs, operating processes, and outputs. A production process can continue, requiring maintenance activities (maintenance) of production equipment and machines. According to [1] [2], maintenance is defined as a factory maintenance activity for repairing, necessary or replacing necessary so that a state of production operation is in accordance with what was agreed upon.

This can be solved by reducing congestion or overcoming as little as possible so the system can work efficiently. But often what happens is that negligence and new treatment that is approved damage has occurred in the production system which causes maintenance costs. However, maintenance carried out completely and regularly will be useful to ensure the continuity of the production process and the life of the production facility.

PT. Meratus Jaya Iron \& Steel is a company engaged in the production of iron ore into semi-finished products (Iron Reduction Kiln / IRK). For companies, machines do play a very important and vital role in supporting the production process. The cause of almost all production processes that use machines. Any damage or disruption to the production machine can cause the production process to stop. Therefore, planned and well maintained is very important so that the production process runs easily, because as we know about damage to machinery or production equipment is unavoidable. 
Research conducted on German Rotary Machines is quite high in the company. Rotary Kiln is a place to take the iron ore reduction produced called iron kiln reduction or commonly called sponge iron (sponge iron). The selection of research in this Rotary Kiln is due to the production machines which often occur depending on the problem. Based on the above considerations, the researcher wrote the title of the final report entitled Analysis of Results (Reliability) of Rotary Kiln $a$ and Rotary Kiln b (Case Study: PT. Meratus Jaya Iron \& Steel).

\subsection{Maintenance System}

Maintenance definitions that describe maintenance are found in [2], [3], [4]. Machine maintenance activities are an integral part of production activities. Maintenance activities have a very large influence on the smooth running of the factory. Maintenance goals achieved in a factory or industry are not only supported by facilities or maintenance techniques, but are also influenced by a management system that is applied.

Maintenance is a concept of all activities required to maintain or maintain the quality of the equipment so that it can function properly as before. The selection of the right maintenance strategy can increase readiness and reliability and reduce the rate of damage to facilities and machinery. According to [5], maintenance is an activity carried out to maintain or repair each facility so that it is in an acceptable condition according to the applicable standards at a reasonable cost. The goals of treatment according to [6] are:

a. Maximize production with the lowest cost, highest quality and optimum safety standards.

b. Identify and application costs.

c. Gather information about required maintenance costs.

d. Provides accurate maintenance recording data.

e. Optimize maintenance resources.

f. Minimize energy use.

g. Minimize the availability of spare parts in the warehouse.

\subsection{Reliability Theory}

Maintenance of components or equipment cannot be separated from the discussion about reliability (Reliability). In addition to reliability is a measure of the success of the maintenance system also reliability is used to determine the scheduling of maintenance itself. Lately the concept of reliability is also used in various industries, for example in determining the number of parts in maintenance and scheduling maintenance. Measuring the success of a treatment action can be stated with the level of Reliability. In general, Reliability can be defined as the probability of a system or product being able to operate properly without experiencing damage to a certain condition and a predetermined time. [2] Based on the definition of Reliability, it is divided into five main components, namely:

a. Probability, Is the first main component, is a numerical input for assessing the reliability of a system which is also a quantitative index to assess the feasibility of a system. Indicates that Reliability states the possibility is valued from 0-1.

b. Expected ability (Satis factory Performance), This component gives a specific sign that the criteria for determining satisfaction levels must be clearly described. For each unit there is a standard to determine what is meant in the expected capabilities. 
c. Desired destination, Desired goals, where the use of equipment must be specific. This is due to several levels in producing a consumer item.

d. Time is a part that is connected with the level of system performance, so it can determine a schedule in the Reliability function. when used is MTBF (Mean Time Between Failure), MTTF (Mean Time To Failure), MTTR (Mean Time To Repair).

e. Operating Conditions (Specified Operating Condition), Environmental factors such as: vibration (vibration), inertia (humidity), geographical location which is the condition where the operation takes place, is included in this condition. Factors - the factors are not only addressed for conditions over a certain period of time when the system or product is operating, but also when the system or product is in storage or is being transformed from one location to another.

\subsection{Benefits of Reliability}

The main purpose of a reliability study is to provide information as a basis for making decisions. In addition, Reliability theory can be used to predict when a spare part on a machine is damaged, so as to determine the level of inventory of production machinery parts.

Inspection is used to determine whether the system is still in a state that meets the desired conditions or not. Can schedule repairs at the time of the component before damage or breakdown occurs.

\subsection{Method of analysis}

In Reliability theory there are two methods of analysis

a. Qualitative Analysis Method, The method of analysis is based on past experience.

b. Quantitative Analysis Method, The method of analysis carried out by calculation, which is carried out can consist of statistics.

\subsection{Distribution Pattern Reliability}

In determining the reliability of a component, the factors that can be interconnected are the rate of damage and time. The following is the relationship between the rate of damage with reliability as shown in Figure 1.

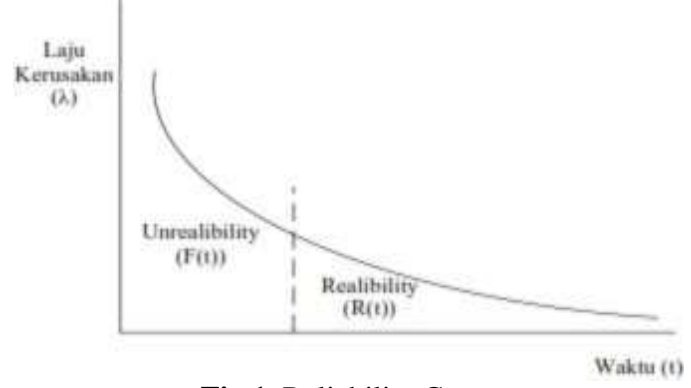

Fig.1. Reliability Curve

From the picture above it is explained that what unrealibility is said if a device or machine with a high damage rate with a shorter operating time. The unit of damage is failure per time. If the failure is high and the operating time of a device is low then it is said to be unreliability. It is said reliability if the level of damage is small and the time to operate the tool is longer. 
Here what if the failure of a small device at a longer operating time.

Researchers use the Weibull Distribution because the Weibull Distribution was created specifically to determine life. Based on this it is assumed that the appropriate distribution is the Weibull Distribution. Weibull is a simple empirical distribution that represents the actual data. This distribution is commonly used in describing component damage characteristics. The functions of the Weibull distribution are as follows:

\section{a. CDF(Cumulative Distribution Function)}

Cumulative distribution function or Cumulative Distribution Function is a function that sums the likelihood value to a certain event as it is known that the number of likelihood values is 1 . The usefulness of the CDF is to find out the probability (probability) in a randomized experiment. CDF has a condition that is $0 \leq \mathrm{F}(\mathrm{t}) \leq 1$ and $\mathrm{F}$ (t) is a non decreasing function (the function is not monotonous data / data is random) as for the cdf function as follows (1):

$$
F(t)=1-e^{-\left(\frac{t}{\theta}\right)^{\beta}}
$$

where :

$$
\begin{array}{ll}
F(\mathrm{t}) & =\text { Cumulative Distribution Function }(\%) \\
t & =\text { Time (hours) } \\
\theta & =\text { Form Parameters of the Weibull Distribution } \\
\beta & =\text { Scale parameters of the Weibull Distribution }
\end{array}
$$

\section{b. Reliability}

The reliability function $\mathrm{R}(\mathrm{t})$ is a reliability function to determine a component system or sub-system running according to its ability at a certain time. The function of reliability, namely:

$$
R(t)=e^{-\left(\frac{t}{\theta}\right)^{\beta}}
$$

where :

$$
\begin{aligned}
& R(\mathrm{t})=\text { Reliability }(\%) \\
& t \quad=\text { Time (hours) } \\
& \theta \quad=\text { Weibull Form Parameters of the Weibull Distribution } \\
& \beta \quad=\text { Weibull Scale parameters of the Weibull Distribution }
\end{aligned}
$$

\section{c. Failure Rate}

The level of failure or the level of damage is a major requirement of an item or subsystem component which at certain intervals will fail. The function of the failure rate is: 


$$
h(t)=\frac{\beta}{\theta}\left(\frac{t}{\theta}\right)^{\beta-1}
$$

where :

$$
\begin{array}{ll}
h(\mathrm{t}) & =\text { Failure rate } \\
t & =\text { Time (hours) } \\
\theta & =\text { Weibull Form Parameters of the Weibull Distribution } \\
\beta & =\text { Weibull Scale parameters of the Weibull Distribution }
\end{array}
$$

\section{d. Mean}

The average life time value can be taken from the Weibull Distribution using the following function.

$$
E(t)=\theta \cdot \Gamma\left(1+\frac{1}{\beta}\right)
$$

where :

$$
\begin{array}{ll}
E(\mathrm{t}) & =\text { Average Life (hours) } \\
t & =\text { Time (hours) } \\
\theta & =\text { Weibull Form Parameters of the Weibull Distribution } \\
\beta & =\text { Weibull Scale parameters of the Weibull Distribution } \\
\Gamma & =\text { Gamma function, taken from the Gamma function table }
\end{array}
$$

\section{e. Mean Time to Repair (MTTR)}

Average repair time (MTTR) is the average time a component has been repaired. Mean Time To Repair MTTR is the time used for repair time. The MTTR for Weibull distributed data is expressed in the following equation:

$$
M T T R=\theta \cdot \Gamma\left(1+\frac{1}{\beta}\right)
$$

where :

$$
\begin{array}{ll}
\text { MTTR } & =\text { Average Life (hours) } \\
t & =\text { Time (hours) } \\
\theta & =\text { Weibull Form Parameters of the Weibull Distribution } \\
\beta & =\text { Weibull Scale parameters of the Weibull Distribution } \\
\Gamma & =\text { Gamma function, taken from the Gamma function table }
\end{array}
$$

\section{Methods}

The steps taken in the research are shown in Figure 2. Starting from the initial survey, then termination of the main problem is supported from field studies and literature studies, followed 
by the goal of solving the problem from the main problems that have been taken, then carried out data collection namely data on the operation of the Rotary Kiln machine, Rotary Kiln repair data, from data collection followed by data processing, pareto diagram was made, followed by Weibull Distribution and distribution results were calculated and obtained data using Minitab Software 17.0. The results of data processing are then analyzed how to solve the problem. After

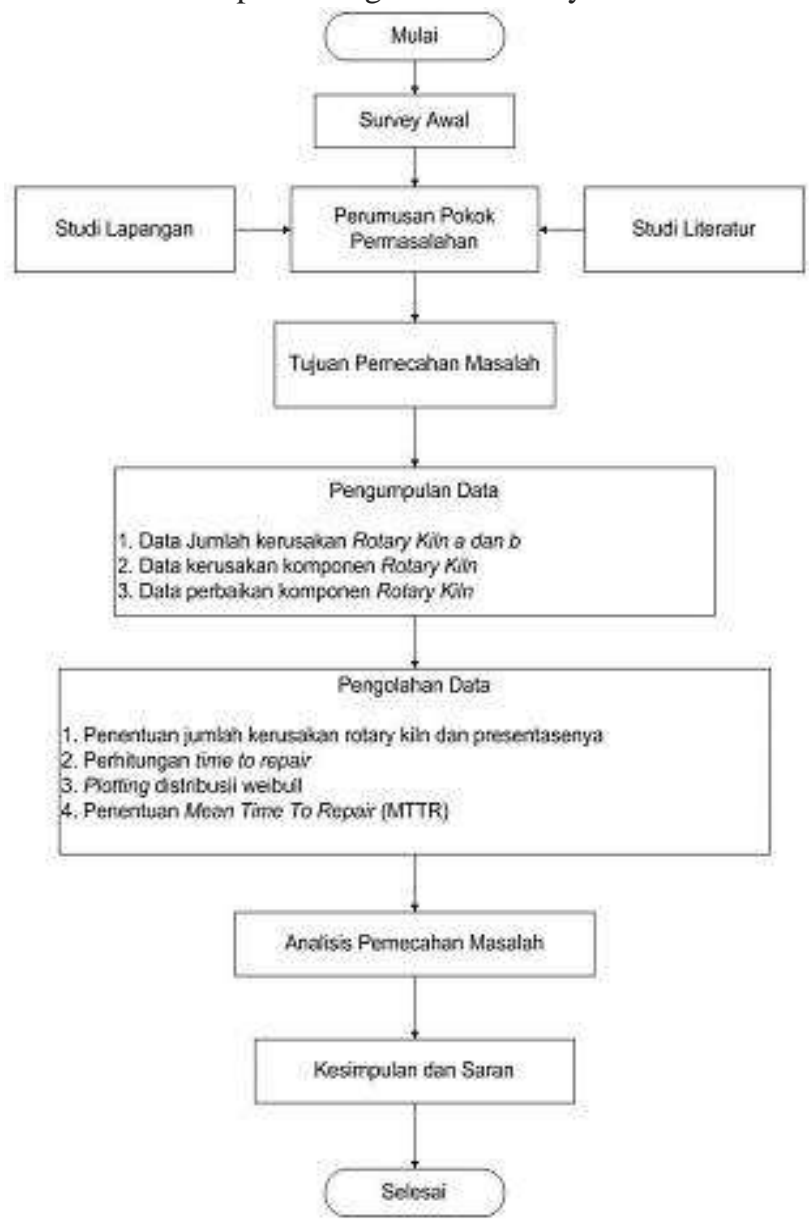

completion, conclusions and suggestions are drawn.

Fig.2. Research methods

\section{Result And Discussion}

\subsection{Processing of Rotary Kiln Data a}

The following is the type of damage and the frequency of damage on the Rotary Kiln Machine that has been grouped can be seen in Table 1. The researcher took the data in the production period from August 2013 to June 2014. 
Table 1. Type of Damage and Frequency of Rotary Kiln Damage a

\begin{tabular}{ccc}
\hline No. & Damage data & number / frequency \\
\hline 1 & cleaning transfer chute \& accretion & 1 \\
\hline 2 & cleaning transfer chute \& accretion & 1 \\
\hline 3 & cleaning bourder \& acression & 1 \\
\hline 4 & cleaning bourder \& acression & 1 \\
\hline 5 & cleaning bourder \& acression & 1 \\
\hline 6 & cleaning bourder \& acression & 1 \\
\hline 7 & cleaning bourder \& acression & 1 \\
\hline 8 & cleaning bourder \& acression & 1 \\
\hline 9 & cleaning bourder \& acression & 1 \\
\hline 10 & cleaning bourder \& acression & 1 \\
\hline
\end{tabular}

Based on the data of the type of damage along with the frequency above, it can be processed into a Pareto Diagram as shown in Figure 3.

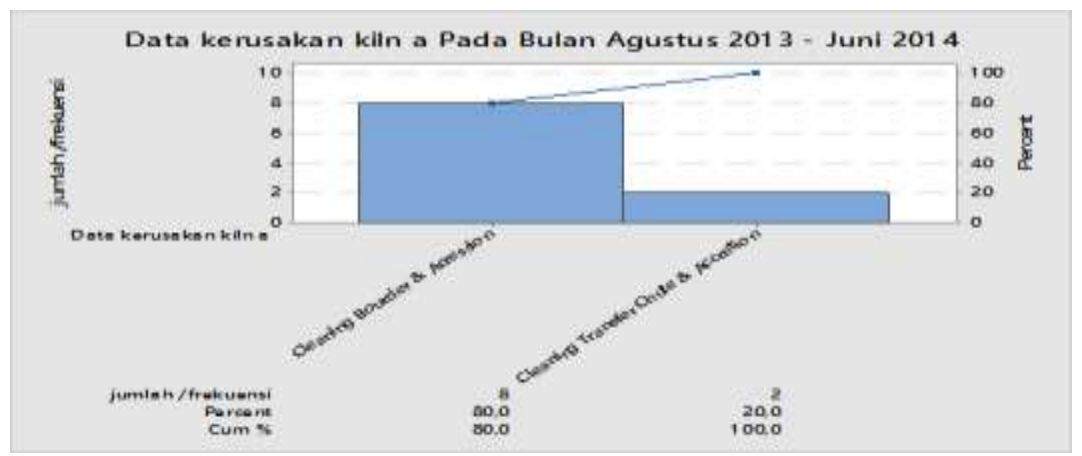

Fig.3. Pareto Rotary Kiln Diagram a

The following is the Rotary Kiln repair data can be seen in table 2. Which is as follows:

Table 2. Time to Repair data

\begin{tabular}{ccc}
\hline \multicolumn{3}{c}{ Data Time To Repair Rotary Kiln a (hour) } \\
\hline 313 & 744 & 744 \\
\hline 164 & 616 & 394 \\
\hline 392 & 532 & - \\
\hline 744 & 720 & - \\
\hline
\end{tabular}

The Weibull distribution plot in the Time To Repair data is shown in Figure 4. Which is as follows: 


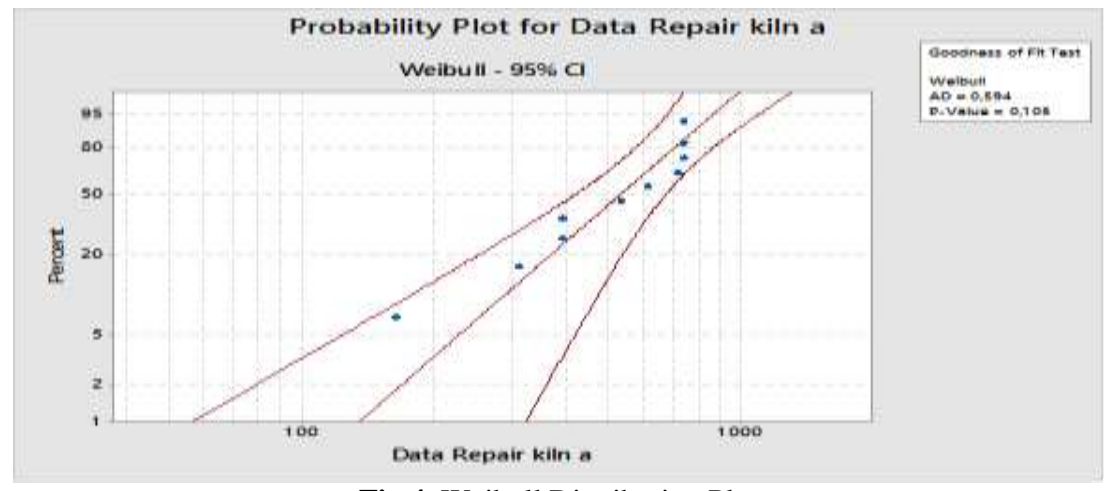

Fig.4. Weibull Distribution Plot

Because the target p-value of the Weibull Distribution from the results of the Minitab Software 17.0 results 0.105 is greater than the $\alpha$ value (set at 0.05 ), it can be concluded that the Weibull Distribution can be used as a representation of that group of data.

To determine the Weibull Distribution parameters by looking at the Identification Distribution of the results of the Minitab Software 17.0 namely in Figure 5.

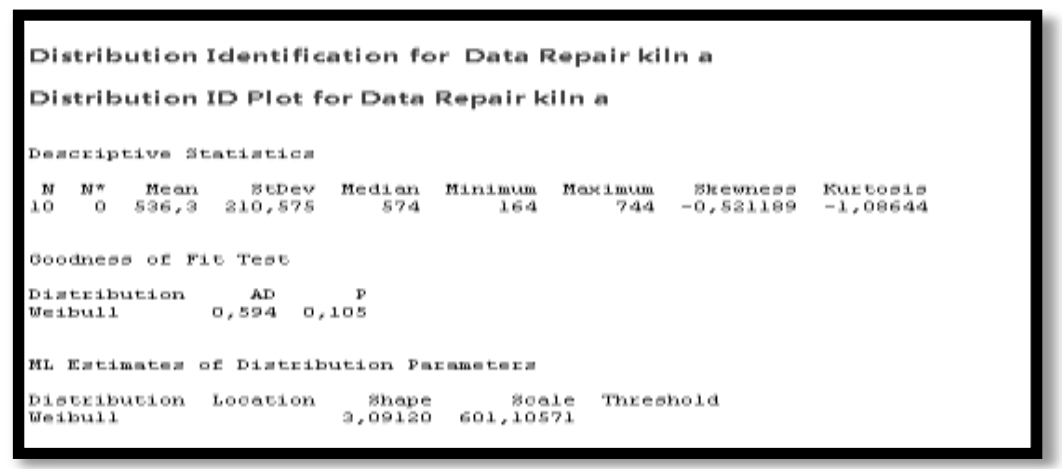

Fig.5. Identification Distribution

From the picture above it can be seen that the scale parameter value $\theta=601.10571$ and the value of the form parameter $\beta=3.09120$ from the Time To Repair data. After the parameters $\theta$ and $\beta$ proceed with the MTTR calculation on Rotary Kiln a, which is as follows:

$$
\operatorname{MTTR}=\theta \cdot \Gamma\left(1+\frac{1}{\beta}\right)
$$

(5)

$$
\begin{gathered}
M T T R=601,10571 . \Gamma\left(1+\frac{1}{3,09120}\right) \\
\text { MTTR }=601,10571 * \Gamma(1,323499) \\
\text { MTTR }=601,10571 *(0,89464) \\
\text { MTTR }=537,7732 \text { hours }
\end{gathered}
$$

From the MTTR calculation results on Rotary Kiln a the results were 537.7732 hours 
The following is the life time data of the Rotary Kiln Machine can be seen in table 3 . Which is as follows:

Table 3. Rotary Kiln Life Time Data a

\begin{tabular}{ccc}
\hline No & Machine name & Life Time (cycle) \\
\hline 1 & Rotary Kiln a & 386 \\
\hline 2 & Rotary Kiln a & 556 \\
\hline 3 & Rotary Kiln a & 459 \\
\hline 4 & Rotary Kiln a & 328 \\
\hline 5 & Rotary Kiln a & 56 \\
\hline 6 & Rotary Kiln a & 212 \\
\hline
\end{tabular}

The Weibull distribution plot in Life Time data is shown in Figure 6. Which is as follows:

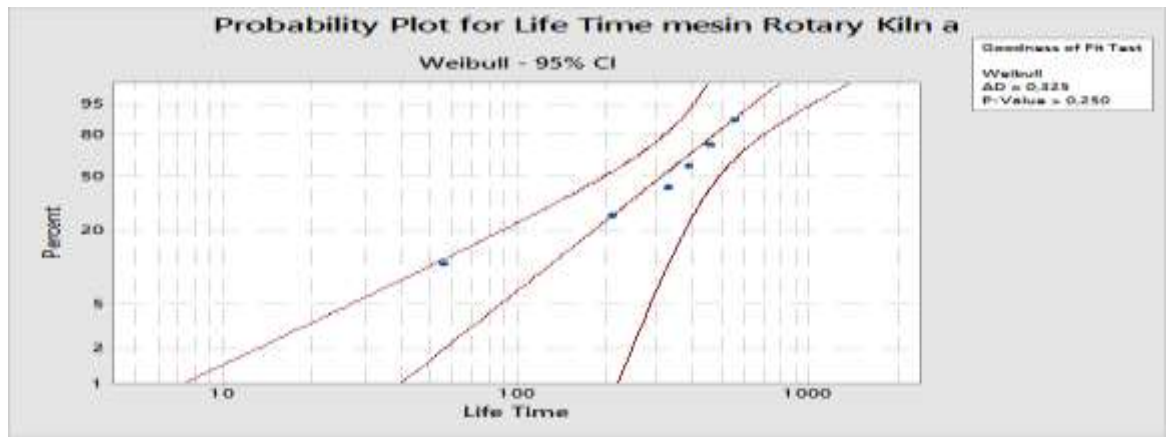

Fig.6. Weibull Distribution Plot

Because the p-value of the Weibull Distribution from the results of the Minitab Software 17.0 results $>0.250$ is greater than the $\alpha$ value (which is set at 0.05 ), it can be concluded that the Weibull Distribution can be used as a representation of that group of data.

To determine the parameters of the Weibull Distribution by looking at the Identification Distribution of the results of the Minitab Software 17.0 namely in Figure 7.

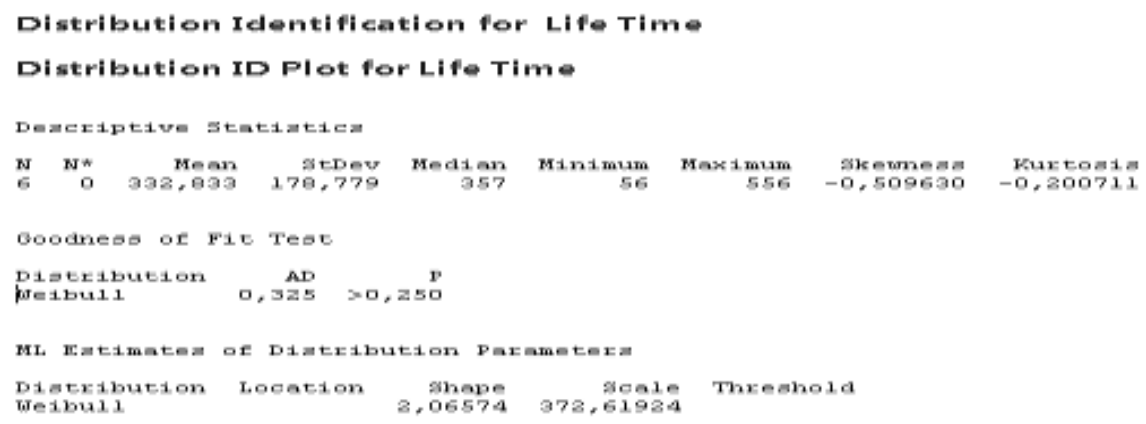

Fig.7. Identification Distribution 
From the picture above it can be seen that the value of the scale parameter $\theta=372.61924$ and the value of the form parameter $\beta=2.06574$ from the Life Time data. After the parameters $\theta$ and $\beta$ continue with the CDF calculation, Reliability, Failure Rate, Mean on Rotary Kiln a, which are as follows:

\subsubsection{CDF ( Cumulatif Distribution Function )}

Researchers took the distance of operating time or life time of Rotary Kiln that is with an average time of two Rotary Kiln a and Rotary Kiln b of 296 hours.

$$
\begin{gathered}
F(t)=1-e^{-\left(\frac{t}{\theta}\right)^{\beta}} \\
F(t)=1-e^{-\left(\frac{296}{372,61924}\right)^{2,06574}} \\
F(\mathrm{t})=1-0,5371 \\
F(\mathrm{t})=0,4629
\end{gathered}
$$

From the CDF calculation results on Rotary Kiln a, the percentage of damage was $0.4629(46.29 \%)$.

\subsubsection{Reliability}

Researchers took the distance of operating time or life time of Rotary Kiln that is with an average time of two Rotary Kiln a and Rotary Kiln b of 296 hours.

$$
\begin{gathered}
R(t)=e^{-\left(\frac{t}{\theta}\right) \beta} \\
R(t)=e^{-\left(\frac{296}{372,61924}\right)^{2,06574}} \\
R(t)=0,5371
\end{gathered}
$$

From the results of the calculation of Reliability in Rotary Kiln obtained a result of $0.5371(53.71 \%)$ hours

\subsubsection{Failure Rate}

Researchers took the distance of operating time or life time of Rotary Kiln that is with an average time of two Rotary Kiln a and Rotary Kiln b of 296 hours.

$$
\begin{gathered}
h(t)=\frac{\beta}{\theta}\left(\frac{t}{\theta}\right)^{\beta-1} \\
h(t)=\frac{2,06574}{372,61924}\left(\frac{296}{372,61924}\right)^{2,06574-1} \\
h(t)=0,00554(0,7944)^{1,06574} \\
h(t)=0,00554(0,7825) \\
h(t)=0,00434
\end{gathered}
$$


From the calculation of the Failure Rate on Rotary Kiln a the result is 0.00434 failures / hour

\subsubsection{Mean}

Then the Mean calculation (average life of a Rotary Kiln Machine) is calculated as follows:

$$
\begin{gathered}
E(t)=\theta \cdot \Gamma\left(1+\frac{1}{\beta}\right) \\
E(t)=372,6194 \cdot \Gamma\left(1+\frac{1}{2,06574}\right) \\
E(t)=372,6194 \cdot \Gamma(1,48) \\
E(t)=372,6194 x 0,88575 \\
E(t)=330,0475
\end{gathered}
$$

From the results of the calculation of the Mean in Rotary Kiln a obtained a result of 330.0475 hours.

\subsection{Rotary Kiln Data Processing b}

The following is the type of damage and the frequency of damage on the Rotary Kiln $b$ Machine that has been grouped can be seen in Table 4. The researcher took the data in the production period from August 2013 to June 2014.

Table 4. Type of Damage and Frequency of Rotary Kiln Damage b

\begin{tabular}{ccc}
\hline No. & Damage data & number / frequency \\
\hline 1 & blocking transfer chute & 1 \\
\hline 2 & lump ore empety stock & 1 \\
\hline 3 & repair conveyor & 1 \\
\hline 4 & cleaning bourder \& acression & 1 \\
\hline 5 & cleaning bourder \& acression & 1 \\
\hline 6 & lump ore empety stock & 1 \\
\hline 7 & lump ore empety stock & 1 \\
\hline 8 & lump ore empety stock & 1 \\
\hline 9 & lump ore empety stock & 1 \\
\hline 10 & cleaning bourder \& acression & 1 \\
\hline 11 & cleaning bourder \& acression & 1 \\
\hline 12 & lump ore empety stock & 1 \\
\hline 13 & cleaning bourder \& acression & 1 \\
\hline
\end{tabular}

Based on the data of the type of damage and frequency above, it can be processed into Pareto Diagrams as shown in Figure 8. 


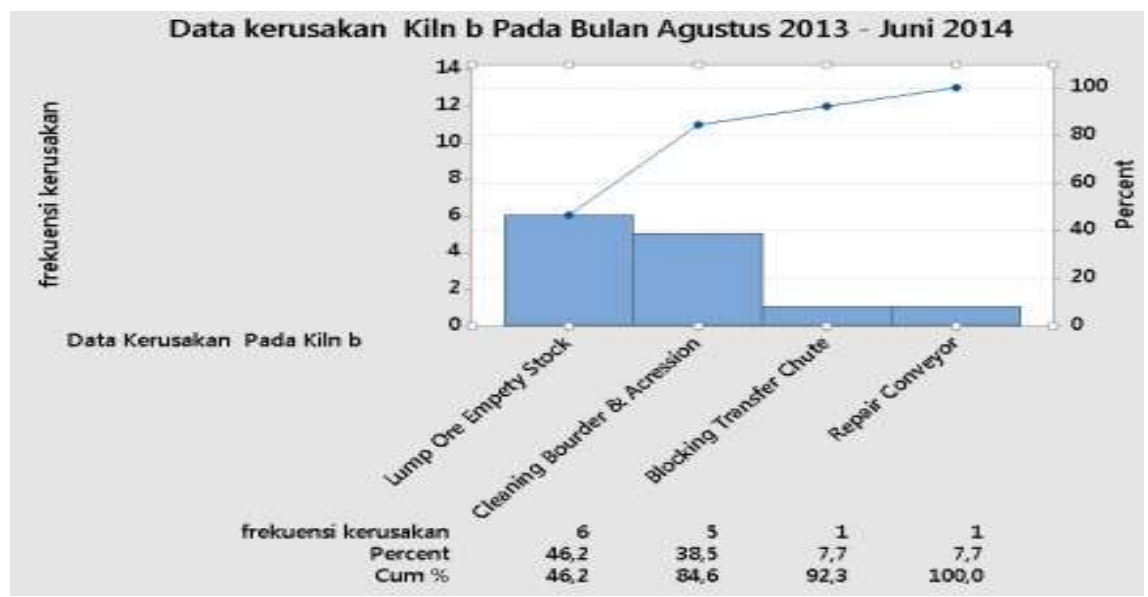

Fig.8. Pareto Rotary Kiln Diagram b

The following is the Rotary Kiln b repair data can be seen in table 5. Which is as follows:

Table 5. Time to Repair data

\begin{tabular}{ccc}
\hline \multicolumn{4}{c}{ Data Time To Repair Rotary Kiln b (hour) } \\
\hline 16 & 110 & 306 \\
\hline 566 & 55 & 498 \\
\hline 117 & 672 & 106 \\
\hline 213 & 275 & - \\
\hline 298 & 217 & - \\
\hline
\end{tabular}

The Weibull distribution plot in the Time To Repair data is shown in Figure 9.

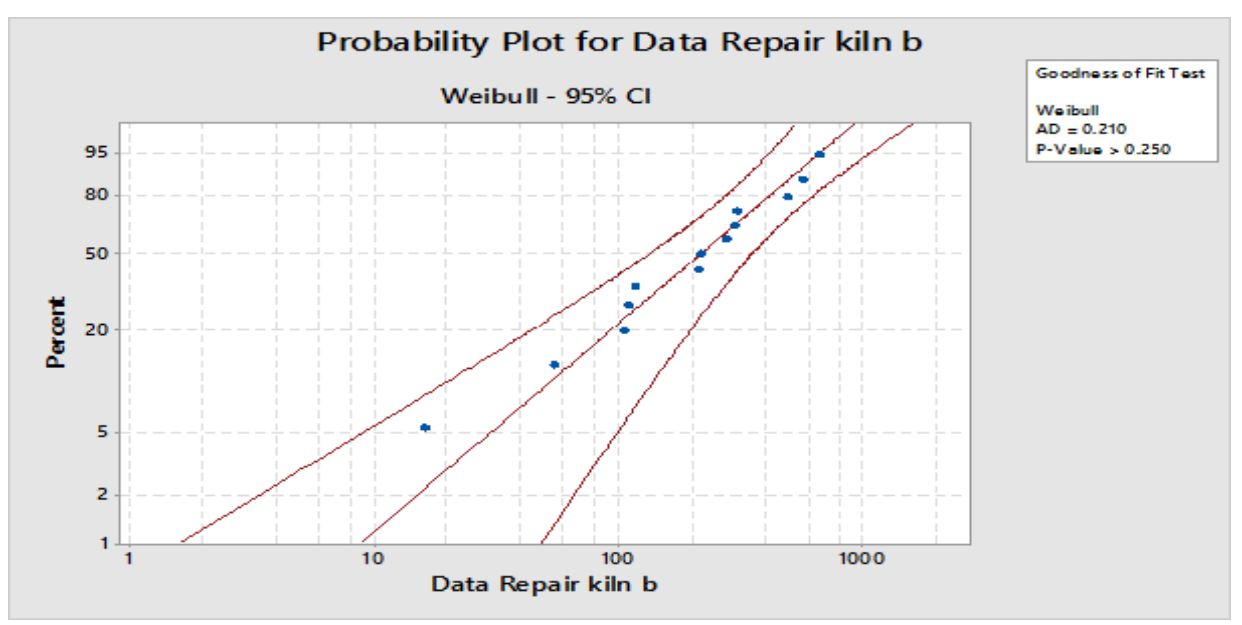


Fig.9. Weibull Distribution Plot

Because the target p-value of the Weibull Distribution from the results of the Minitab Software 17.0 results $>0.250$ is greater than the $\alpha$ value (set at 0.05 ), it can be concluded that the Weibull Distribution can be used as a representation of the data group. To determine the parameters of the Weibull Distribution by looking at the Identification Distribution of the results of the Minitab Software 17.0 namely in Figure 10.

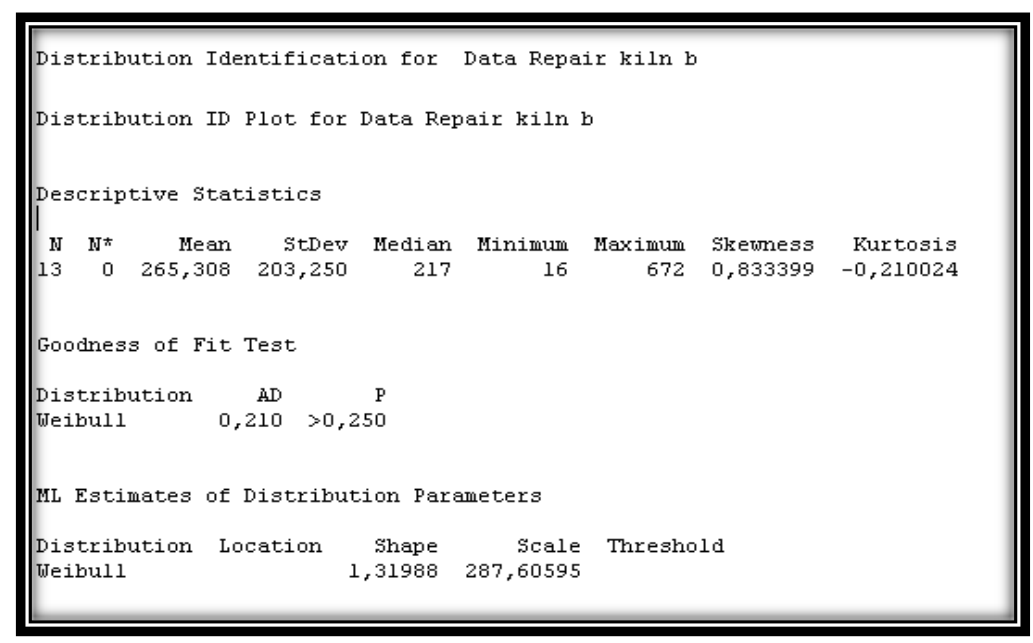

Fig.10. Identification Distribution

From the picture above it can be seen that the value of the scale parameter $\theta=287.60595$ and the value of the form parameter $\beta=1.31988$ from the Time To Repair data. After the parameters $\theta$ and $\beta$ proceed with the MTTR calculation on Rotary Kiln b, as follows:

$$
M T T R=\theta \cdot \Gamma\left(1+\frac{1}{\beta}\right)
$$

(5)

$$
\begin{gathered}
M T T R=287,60595 . \Gamma\left(1+\frac{1}{1,31988}\right) \\
M T T R=287,60595 * \Gamma(1,76) \\
M T T R=287,60595 *(0,91237) \\
M T T R=262,403 \text { hour }
\end{gathered}
$$

From the MTTR calculation results on Rotary Kiln b, the results were 262.403 hours.

The following is the life time data of the Rotary Kiln 6 Machine can be seen in table 6 . Which is as follows: 
Table 6. Rotary Kiln Life Time Data b

\begin{tabular}{ccc}
\hline No & Machine name & Life Time (cycle) \\
\hline 1 & Rotary Kiln b & 249 \\
\hline 2 & Rotary Kiln b & 621 \\
\hline 3 & Rotary Kiln b & 83 \\
\hline 4 & Rotary Kiln b & 78 \\
\hline 5 & Rotary Kiln b & 65 \\
\hline 6 & Rotary Kiln b & 384 \\
\hline 7 & Rotary Kiln b & 446 \\
\hline 8 & Rotary Kiln b & 249 \\
\hline 9 & Rotary Kiln b & 330 \\
\hline 10 & Rotary Kiln b & 122 \\
\hline 11 & Rotary Kiln b & 86 \\
\hline 12 & Rotary Kiln b & 414 \\
\hline 13 & Rotary Kiln b & 246 \\
\hline
\end{tabular}

The Weibull distribution plot in Life Time data is shown in Figure 11. Which is as follows:

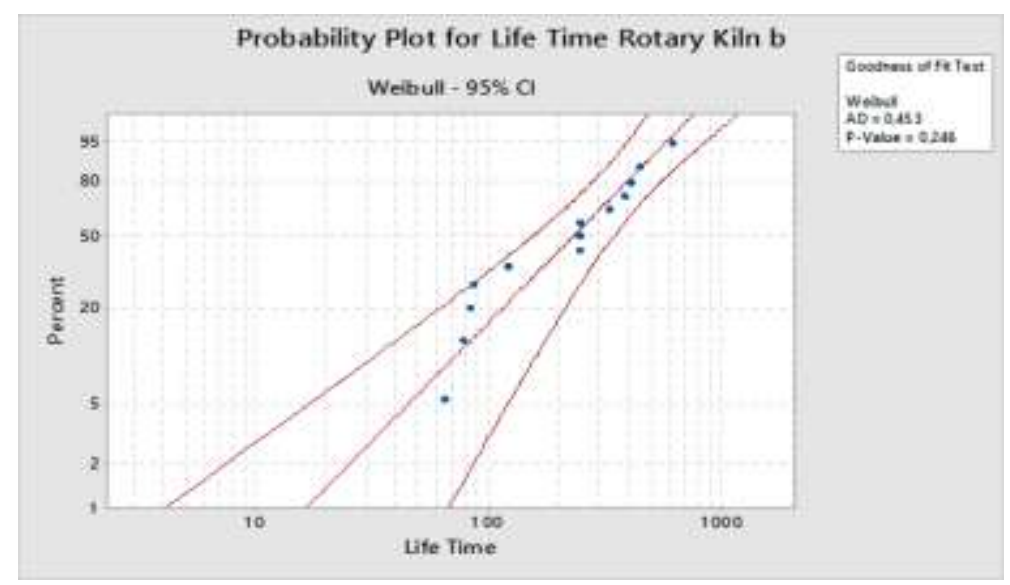

Fig.11. Weibull Distribution Plots Because of the magnitude of the p-value of the Distribution

Weibull from the results of Minitab Software 17.0 obtained 0.246 results greater than the value of $\alpha$ (set at 0.05 ), it can be concluded that the Weibull Distribution can be used as a representation of the data group. To determine the parameters of the Weibull Distribution by looking at the Identification Distribution of the results of the Minitab Software 17.0 namely in Figure 12. 


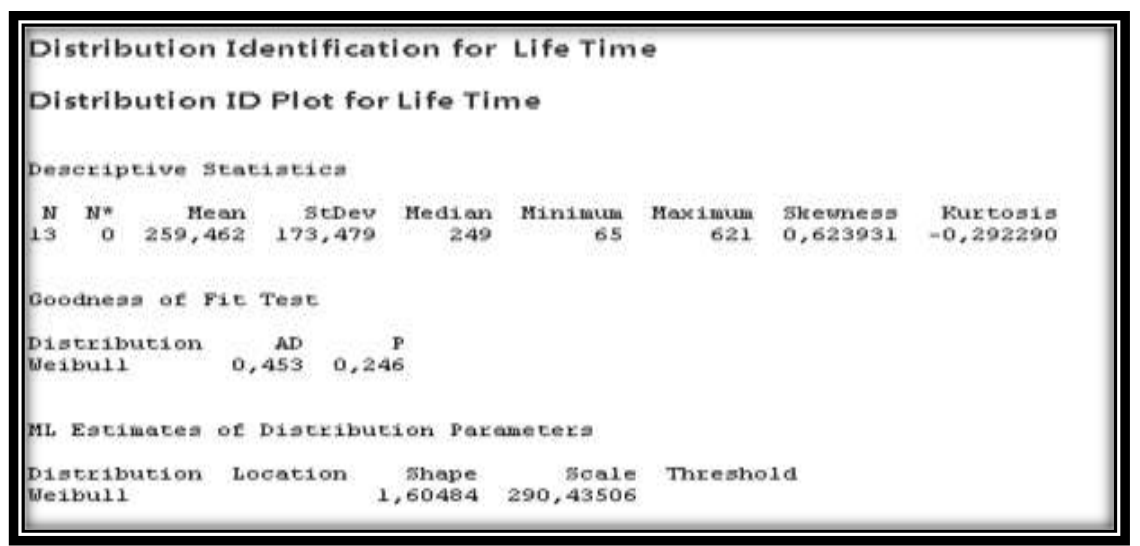

Fig.12. Identification Distribution

From the picture above it can be seen that the scale parameter value $\theta=290.43506$ and the value of the parameter form $\beta=1.60484$ from Life Time data. After the parameters $\theta$ and $\beta$ continue with the CDF calculation, Reliability, Failure Rate, Mean on Rotary Kiln b, as follows:

\subsubsection{CDF ( Cumulatif Distribution Function )}

Researchers took the distance of operating time or life time of Rotary Kiln, with an average time of two Rotary Kiln a and Rotary Kiln b of 296 hours.

$$
\begin{gathered}
F(t)=1-e^{-\left(\frac{t}{\theta}\right)^{\beta}} \\
F(t)=1-e^{-\left(\frac{296}{290,43506}\right)^{1,60484}} \\
F(t)=1-0,3567 \\
F(t)=0,6433
\end{gathered}
$$

From the calculation of CDF on Rotary Kiln b, the percentage of damage was 0.6433 $(64.33 \%)$

\subsubsection{Reliability}

Researchers took the distance of operating time or life time of Rotary Kiln that is with an average time of two Rotary Kiln a and Rotary Kiln b of 296 hours.

$$
\begin{gathered}
R(t)=e^{-\left(\frac{t}{\theta}\right)^{\beta}} \\
R(t)=e^{-\left(\frac{296}{290,43506}\right)^{1,60484}} \\
R(t)=0,3567
\end{gathered}
$$

From the results of the calculation of Reliability in Rotary Kiln b obtained results of $0.3567(35.67 \%)$ hours 


\subsubsection{Failure Rate}

Researchers took the distance of operating time or life time of Rotary Kiln, with an average time of two Rotary Kiln a and Rotary Kiln b of 296 hours..

$$
\begin{gathered}
h(t)=\frac{\beta}{\theta}\left(\frac{t}{\theta}\right)^{\beta-1} \\
h(t)=\frac{1,90484}{290,43506}\left(\frac{296}{290,435064}\right)^{1,90484-1} \\
h(t)=0,00656(1,0192)^{0,90484} \\
h(t)=0,00656(1,0174) \\
h(t)=0,00667
\end{gathered}
$$

From the calculation of the Failure Rate on Rotary Kiln b, the result is 0.00667 failures / hour

\subsubsection{Mean}

Then the mean calculation (average life of the Rotary Kiln b) is calculated as follows:

$$
\begin{gathered}
E(t)=\theta \cdot \Gamma\left(1+\frac{1}{\beta}\right) \\
E(t)=290,43506 \Gamma\left(1+\frac{1}{1,60484}\right) \\
E(t)=290,43506 . \Gamma(1,6) \\
E(t)=290,43506 \times 0,89352 \\
E(t)=259,5
\end{gathered}
$$

From the results of the calculation of the Mean on Rotary Kiln b obtained results of 295.5 hours

\subsection{Comparison of Rotary Kiln Machines a and Rotary Kiln Machines b}

The following is a comparison between Rotary Kiln a and Kiln b can be seen in table 7 .

Table 7. Comparison of the results of Reliability of Rotary Kiln a and Rotary kiln b

\begin{tabular}{cccc}
\hline No & Reliability Analysis & Rotary Kiln a & Rotary Kiln b \\
\hline 1 & CDF with $\mathrm{t}=296$ hour $(\%)$ & 0,4629 & 0,6433 \\
\hline 2 & Reliabilitas, with $\mathrm{t}=296$ hour $(\%)$ & 0,5371 & 0,3567 \\
\hline 3 & Failure Rate $\mathrm{t}=296$ hour & 0,00434 & 0,00667 \\
\hline 4 & Mean (cycle) & 330,0475 & 259,5 \\
\hline 6 & MTTR (hour) & 537,7732 & 262,403 \\
\hline
\end{tabular}

If compared to the Reliability value of the two types of Rotary Kiln a and Rotary Kiln b machines when the average Rotary Kiln is on or equal to 296 hours. The value of Reliability of Rotary Kiln a within 296 hours is 0.5371 in the percentage of $53.71 \%$ and Rotary Kiln Machine 
b of 0.3567 in the percentage is $35.67 \%$. From the results of this percentage it can be proven that the value of the reliability of the Rotary Kiln a machine is higher with a percentage value of $53.71 \%$ compared to the Rotary Kiln Machine b with a percentage value of $35.67 \%$ of the operating data for one year.

Here it can be seen that the usage or life time of a Rotary Kiln a machine is lower than a Rotary Kiln b. Judging from the failure rate of the Rotary Kiln Machine a 0.00434 if at 296 hours. While the failure rate is Rotary Kiln b 0.00667 if at 296 hours. Here it means that in terms of the failure rate of the Rotary Kiln Engine a better failure rate than the Rotary Kiln Engine b when operating time is 296 hours. Judging from the Mean Rotary Kiln can be on, the Rotary Kiln Engine a 330.0475 hours if at 296 hours. While the Mean Kiln Rotary Machine b 259.5 hours in 296 hours. Here it can be seen that the average Rotary Kiln a machine can live 330.0475 hours and the average Rotary Kiln b machine can live 259.5 hours. It can be concluded that the average life of a Rotary Kiln Machine is better than the average life of a Rotary Kiln Machine b.

Next note the value of MTTR, MTTR Is the average time required to repair the Rotary Kiln Machine. It can be seen from the MTTR value on the Rotary Kiln Machine that is 537.7732 hours while the MTTR value on the Rotary Kiln Machine b that is 262,403 hours from the result data it can be concluded that the MTTR on the Rotary Kiln Machine a is higher than the Rotary Kiln Machine b. Why MTTR Rotary Kiln Machines have a greater level of repair, because the type of damage of Rotary Kiln Machines with Boulder \& Acression Cleaning with the highest frequency and the heaviest damage weight is only natural if the repair level is higher.

\section{Company Regulation}

Based on research that has been done researchers can provide input on the company concerned. The following is the Preventive Maintenance scheduling that researchers listed in table 8 .

Table 8. Company's Preventive Maintenance Schedule

\begin{tabular}{llll}
\hline \multicolumn{1}{c}{ Name } & \multicolumn{1}{c}{ Sheck } & Action \\
\hline Rotary feeder & Every day & 10 days - is there a blockage? & $\begin{array}{l}\text { Clean the blockage by destroying the coal } \\
\text { that is clotted in the feeder }\end{array}$ \\
\hline Lobe kompressor & Every day & 10 days - whether it happens Filters on the filter? & Cleaning the filter using a brush \\
Kiln shell & Every day & 10 days - is there a blockage at the kiln outlet? & $\begin{array}{l}\text { Thermocouple checks Are the } \\
\text { between actual and DCS }\end{array}$ \\
\hline Kiln inlet seal & Every day & 10 days - does the impurity occur in the seal? & $\begin{array}{l}\text { Cleaning the seal for lubrication The seals } \\
\text { run smoothly }\end{array}$ \\
\hline Kiln outlet seal & Every day & 10 days - whether it happens Dirt on the seal? & $\begin{array}{l}\text { Cleaning the seal for lubrication } \\
\text { The seals run smoothly }\end{array}$ \\
\hline Main drive & Every day & $\begin{array}{l}10 \text { days - whether lubrication occurs } \\
\text { Optimally on the main drive? }\end{array}$ & $\begin{array}{l}\text { Lubrication must be done periodically } \\
\text { In order to reduce wear on the teeth of } \\
\text { drive }\end{array}$ \\
\hline
\end{tabular}




\begin{tabular}{llll}
\hline Auxelery drive & Every day & $\begin{array}{l}\text { 10 days - whether lubrication occurs } \\
\text { Optimally on the main drive? }\end{array}$ & $\begin{array}{l}\text { Lubrication must be done periodically } \\
\text { In order to reduce wear on the teeth }\end{array}$ \\
\hline Sheell air fan & Every day & $\begin{array}{l}10 \text { days - did the contamination occur } \\
\text { On the fan blade? }\end{array}$ & Cleaning is done on the fan \\
\hline Thermocouple & Every day & $\begin{array}{l}10 \text { days - whether the sensor is on a thermocouple } \\
\text { Works fine? }\end{array}$ & $\begin{array}{l}\text { Thermocouple calibration, } \\
\text { Check the DC sensor with actual }\end{array}$ \\
\hline
\end{tabular}

It can be explained that from the Rotary Kiln component should be checked every day, but the actual preventive maintenance, Rotary Kiln is checked every 10 days based on the average value of the Rotary Kiln b. Researchers take the average time of Rotary Kiln b, the reliability value is smaller than the Rotary Kiln a. From the problems with the rotary feeder, the damage that often occurs is the blockage in the rotary feeder. The solution that we can do is to clear the blockage by destroying the coal that is lumping on the rotary feeder. From the problems in the compressor lobe, the damage that often occurs is impurity in the filter solution that we can do by cleaning the filter using a brush. Of the problems in the kiln shell, the damage that often occurs is the blockage at the kiln outlet (accretion) solution that we can do by checking whether the thermocouple is the same as the DCs with the actual.

From the problems in the kiln inlet seal, the damage that often occurs is the inlet kiln seal solution that we can do by checking the seal so that the lubrication between the kiln shell and the dust setling chamber runs smoothly. Of the problems with the kiln outlet seal, the damage that often occurs is that the kiln outlet seal solution can be done by checking the seal so that the lubrication between the kiln shell and the transfer chute runs smoothly. From the problems with the shell air fan, the damage that often occurs is the fouling on the fan blade. The solution we can do with cleaning the blade is the air fan. Also carried out measurements of air flow between the DCS with the actual. Of the problems with thermocouple damage that often occurs is the error sensor solution that we can do with thermocouple calibration. Also carried out the measurement of temperature between the DCS (Distruted Control System) with the actual.

\section{Conclusion}

From the results of the study it can be concluded that the Rotary Kiln a and Rotary Kiln b machines at the time of calculation of 296 with a Rotary Kiln a Reliability value of 0.5371 and Rotary Kiln b machines of 0.3567 prove that the reliability value of the Rotary Kiln a machine is higher compared to Rotary Kiln machines $b$. The main factor is the reliability value of the engine usage, if the machine is used longer then the reliability value is getting smaller or close to 0 . This is evidenced that the mass of use of Rotary Kiln b is more dominant than the Rotary Kiln Machine a.

Viewed from MTTR to fix on Rotary Kiln Machines. It can be seen from the MTTR value on the Rotary Kiln a Machine that is 537.77732 while the MTTR value on the Rotary Kiln Machine $b$ that is 262,403 from the result data it can be concluded that the MTTR on the Rotary Kiln Machine a is higher than that of the Rotary Kiln Machine b. MTTR Rotary Kiln a large value because the frequency of rotary Kiln a damage at the heaviest damage weights, namely Cleaning Boulder \& Acression with the highest damage frequency. So it is appropriate if Rotary Kiln a has a relatively longer repair time compared to Rotary Kiln b. 


\section{References}

[1] A. S., Manajemen Produksi dan Operasi, Refisi ed., Jakarta: Fakultas Ekonomi, Universitas Indonesia, 2008.

[2] A. Sofjan, Manajemen Produksi dan Operasi, 4 ed., Jakarta: Fakultas Ekonomi Universitas Indonesia, 1993.

[3] V. Gasperz, Analisis Sistem Terapan Berdasarkan Pendekatan Teknik Industri, Pertama ed., Bandung: Tarsito.

[4] P. Gopalakrishnan and A. K. And Banerji, Maintenance and Spare Part Managements, New Delhi: Prentice Hall, 1997.

[5] S. "Manajemen Perawatan Industri," Ganeca Exact, Bandung, 1988.

[6] T. Wireman, World Class Maintenance Management, 1st ed., New York: Industrial Press, 1990.

[7] B. S. Abbas, E. Steven, H. Christian and T. Sumanto, Penjadwalan Preventice Maintenace Mesin B.Fulte Pada PT. AMW, Jakarta Barat: Teknik Industri, Fakultas Teknik, Universitas Bina Nusantara.

[8] H. Handoko, Dasar - Dasar Manajemen Produksi dan Operasi, Jakarta : BPFE, 1997.

[9] I. H. Bangun, A. Rahman and Z. Darmawan, Perencanaan Pemeliharaan Mesin Produksi Dengan Menggunakan Metode Reliability Centred Maintenance (RCM) II Pada Mesin Blowing OM PT. Meratus Jaya Iron \& Steel, Jilid 1 ed., vol. Jilid 1, Batulicin, Kalimantan Selatan: General Technical Specification PT. Meratus Jaya Iron \& Steel, 2008.

[10] A. R. Sachbudi and A. Setiawan, "Analisa Keandalan Kompenen Kritis Lift NPX - 36000 Untuk Menentukan Jadwal Perawatan Pencegahan yang Optimum".

[11] G. Yusfiq, "Penerapan Sistem Perawatan Menggunakan Metode Reliability Centred Maintenace (RCM) Pada Mesin Loom LSL-4 (Studi Kasus : PT. DASARPLAST NUSANTARA)". 